University of Nebraska - Lincoln

DigitalCommons@University of Nebraska - Lincoln

\title{
Personal and Political Reconciliation in Post-Genocide Rwanda
}

Ari Kohen

University of Nebraska-Lincoln, akohen2@unl.edu

Michael Zanchelli

Washington, D.C.

Levi Drake

Washington, D.C.

Follow this and additional works at: https://digitalcommons.unl.edu/poliscifacpub

Part of the Political Science Commons

Kohen, Ari; Zanchelli, Michael; and Drake, Levi, "Personal and Political Reconciliation in Post-Genocide Rwanda" (2011). Faculty Publications: Political Science. 44.

https://digitalcommons.unl.edu/poliscifacpub/44

This Article is brought to you for free and open access by the Political Science, Department of at DigitalCommons@University of Nebraska - Lincoln. It has been accepted for inclusion in Faculty Publications: Political Science by an authorized administrator of DigitalCommons@University of Nebraska - Lincoln. 
Published in Social Justice Research (2011); doi: 10.1007/s11211-011-0126-7

Copyright ( 2011 Springer Science+Business Media, LLC. Used by permission.

Published online March 15, 2011.

\title{
Personal and Political Reconciliation in Post-Genocide Rwanda
}

\author{
Ari Kohen \\ Department of Political Science, University of Nebraska-Lincoln, Lincoln, NE, USA
}

\author{
Michael Zanchelli and Levi Drake \\ Washington, DC, USA \\ Corresponding author - Ari Kohen, email akohen2@unl.edu
}

\begin{abstract}
The majority of scholarly research on Rwanda currently focuses on determining the causes of and participation in the genocide. In this paper, we explore a variety of questions that have come to the forefront in post-genocide Rwanda. In particular, we are concerned with the prospects for peace and justice in the aftermath of the gross abuses of human rights that occurred and, to that end, we consider the potential uses and limits of restorative justice initiatives in the process of healing and reconciliation in Rwanda. We argue that restorative justice initiatives have moved the country closer toward reconciliation than retributive measures, such as the International Criminal Tribunal for Rwanda. That said, we also suggest that the Rwandan government, despite claims that it seeks to achieve reconciliation, has not shown a serious commitment to healing the wounds that persist between either individual Rwandans or the groups that they comprise. In the end, then, we make a case for the importance of pairing a comprehensive search for justice in Rwanda with a commitment to truth-telling and accountability by the victims and perpetrators of the genocide, as well as by current government officials.
\end{abstract}

Keywords: Rwanda, South Africa, transitional justice, restorative justice, genocide, human rights, apartheid, reconciliation, forgiveness

In the past 5 years there has been an explosion of literature, history, and film chronicling the genocide in the tiny African country of Rwanda. This recent outpouring of interest occurred around the tenth anniversary of the massacres. It 
was common, in the preceding 7 years, to find large numbers of intelligent, wellread, and well-travelled people with no awareness that an instance of genocide had occurred in their lifetimes; it is not so likely today. That said the majority of scholarly research on Rwanda currently focuses on determining the causes of and participation in the genocide. In this paper, however, we explore a variety of questions that have come to the forefront in post-genocide Rwanda. In particular, we are concerned with the prospects for peace and justice in the aftermath of the gross abuses of human rights that occurred and, to that end, we consider the potential uses and limits of restorative justice initiatives in the process of healing and reconciliation in Rwanda.

Following the 1994 genocide, the predominately Tutsi-led Rwandan government was left with the staggering tasks of instituting justice, restoring some measure of order, and fostering reconciliation within Rwandan society. In his powerful book about the genocide and its aftermath, We wish to inform you that tomorrow we will be killed with our families, Gourevitch (1998) ably documents the problem of how the new government, dominated by members of the Tutsi-led Rwandan Patriotic Front, might sort through the overwhelming number of ordinary Hutu who participated in hundred days of killing. As he notes, "Nobody ever talked seriously about conducting tens of thousands of murder trials in Rwanda. Western legal experts liked to say that even the lawyer-crowded United States could not have handled Rwanda's caseload fairly and expeditiously" (Gourevitch, 1998, 249). Despite the impossibility of trials - due to the sheer numbers and also to the fact that Rwanda's courts were shut down for more than 2 years after the genocide - the government carried out more than a hundred and twenty-five thousand arrests by 1997 (Gourevitch, 1998, 242). Over the years, the government has been much criticized by various human rights organizations for the prison conditions faced by these detainees and for the amount of time that accused génocidaires are imprisoned without trial. ${ }^{1}$ Its response has been to occasionally conduct mass releases and, since 2003, between fifty and sixty thousand inmates have been set free; the most recent such release occurred on February 19, 2007, when eight thousand prisoners - deemed not to be masterminds of the genocide - were released "to ease overcrowding in the prisons and to foster reconciliation" (Asiimwe, 2007, 1).

These releases, however, have been met with considerable animosity from genocide survivors and their advocates, and the released prisoners are seldom welcomed back into their communities. Given that a great many - if not all - of the prisoners are, in fact, guilty of the crimes for which they have been imprisoned and that few - if any - have ever stood trial to answer for those crimes, this reaction likely comes as no surprise. Indeed, suspicions run high with regard to the motives of these newly freed génocidaires and often with good reason, as

1 Gourevitch $(1998,246)$ describes a visit to one such prison: “At Gitarama, more than six thousand men were packed into a space built for seven hundred and fifty. That worked out to four prisoners per square yard: night and day, the prisoners had to stand or sit between the legs of those who stood, and even in the dry season a scum of condensation, urine, and bits of dropped food covered the floor. The cramped prisoners' feet and ankles, and sometimes their entire legs, swelled to two or three times normal size. They suffered from an atrophying of their swollen extremities and from rot; infection often followed. Hundreds had required amputations." 
Asiimwe $(2007,1)$ points out that "Hundreds already freed have since been rearrested after committing other crimes, many while trying to destroy evidence related to their alleged involvement in the genocide." While the releases are undoubtedly helping to reduce the prison population, it is markedly less clear in what sense the government's program is actively promoting reconciliation between Hutu and Tutsi in Rwanda.

In this paper we suggest that a great deal more could be done to begin the process of reconciliation and ensure justice in post-genocide Rwanda. We begin by clearly establishing the theoretical groundwork for our propositions, setting out a clear distinction between personal and political of reconciliation. In doing so, we are proceeding from the assumption that achieving political reconciliation in Rwanda involves more than the absence of violence between former antagonists. While undoubtedly a solid foundation, we take reconciliation to mean a process that leads to developing a normative interaction between ethnic and political opponents based on mutual acceptance as distinct but equal co-members of the same, larger community.

This background informs our perspective on the intricacies of the Rwandan case and our suggestions for it. We closely examine the traditional gacaca court system and the degree of commitment to reconciliation on the part of the current Rwandan government. Our research into these questions is supplemented by personal interviews, conducted in Rwanda, with those who have been personally affected by the violence. More than simply reflections on the horrors of genocide, the attitudes of interviewees with regard to questions about healing and reconciliation provide us with a framework with which to apply to the case of Rwanda our analysis of the restorative justice literature. We argue that restorative justice initiatives have moved the country closer toward reconciliation than retributive measures, such as the International Criminal Tribunal for Rwanda.

That said, we also suggest that the Rwandan government, despite claims that it seeks to achieve reconciliation, has not shown a serious commitment to healing the wounds that persist between either individual Rwandans or the groups that they comprise. Furthermore, we suggest that official policies adopted by the current Rwandan Executive Branch have actively worked against the type of political reconciliation for which we ultimately advocate. Drawing particularly from the South African case, we make an argument for the importance of pairing a comprehensive search for justice in Rwanda with a commitment to truth-telling and accountability by the victims and perpetrators of the genocide, as well as by current government officials. In the end, we acknowledge the idiosyncrasies and particular challenges of the Rwandan case, but suggest that, in taking measures to establish a more restorative justice, the government can help to begin developing meaningful reconciliation within post-genocide Rwanda.

\section{Theoretical Framework for Justice and Reconciliation}

Given the challenges faced by the Rwandan political leadership and their lack of progress toward genuine reconciliation to date, a greater emphasis on restorative methods would benefit the broader reconciliation process. In thinking about reconciliation, it is important to delineate between two types, personal and po- 
litical, both of which can be thought of as goals of a restorative approach to justice. Generally speaking, the former is concerned with restoring a relationship between victim and offender, while the latter seeks to repair broken trust between hostile groups in the aftermath of international or intrastate conflict. However, in using these terms, it is necessary to understand what fundamentally distinguishes one form of reconciliation from the other, the personal from the political. Delving into the profound dissimilarities between these two forms of reconciliation reveals the immediate priority of one over the other in Rwanda.

Marked distinctions exist between what is generally personal or private from that which is political or public. The political philosophy of Kant and Arendt provide particularly helpful insight into what sets these two spheres apart. As Arendt $(1982,74)$ argues, Kant holds that to be political is to act among humanity. Similarly, Arendt equates the political with the public sphere, or the polis. Thus, "the political" is essentially concerned with a group or society of people and ideas that relate to or affect them as a whole (Arendt, 1958, 12). Consequently, a personal act or idea only achieves a political status when it becomes public and is subjected to publication and discussion within a larger community of ideas (Arendt, 1982, 74).

The important distinction between political and personal realms applies similarly to the concept of reconciliation. Personal reconciliation, simply stated, involves a common understanding among individuals, a particular victim, or covictim, and a particular offender. It is limited to the boundaries of the private sphere and is not inherently related to, nor does it affect, others on a broad public level. Considering reconciliation at the political level is perhaps a bit more difficult to isolate, however. Most broadly, political reconciliation is a moral consensus, as it involves a common understanding and recognition of an event that took place between two conflicting sides. It is a prevalent and accepted "disposition," finding commonality in a world that is "constituted by diverse and possibly incommensurable perspectives" (Schaap, 2003, 3). This fact rings especially true given the deeply engrained "ethnic" divisions that took hold in Rwanda during colonization and throughout its post-colonial history.

In considering concepts like a "common understanding" within a discussion of political reconciliation, it follows that ideas like collective truth and memory are natural-and quite important-additions to the conversation. While truth and memory are commonly discussed in an individual context, applying these concepts collectively is of the utmost importance for political reconciliation (Soyinka, 1999, 81). Of course, because they can be shared truth and memory can be utilized in different ways for varying political ends. While they might be used for personal political gain by sowing dissension, they can also be used to develop a unifying, shared narrative.

Similarly, Cochran $(2002,421)$ conveys the two-fold potential for collective memories. He relates two prominent types of memory that come to the fore in politics - prudential and mythic. Prudential memory is "veridical and literal" (Cochran, 2002, 424), difficult to manipulate but also useful for political decisions. Mythic memory, by contrast, is "nonliteral" and open to control, leaving it to be potentially either politically constructive or destructive. "There may be cases in which it is best not to have a good, literal memory," he explains, "occasions in 
which it is prudent to forget in order to clear space for new initiatives and alliances" (Cochran, 2002, 424). Cochran $(2002,424)$ continues to explain the role of mythic memory in the construction of cultural ideologies and political identities as memories are passed on from tales and cultural influences from beyond the bounds of common political discourse. For Cochran $(2002,425)$, then, memories and rituals become the sources of power necessary to either prolong conflict or reconcile after it.

The pursuit of political reconciliation in a public act of forgiveness could be a practical example of the inventiveness and mythic memory that Soyinka and Cochran discuss. According to Schaap $(2003,5-6)$, political forgiveness is a struggle to settle the meaning of a wrongful act in the past for the sake of our common life as individuals within a community. To forgive in this way is thus to resist the power of the past to determine the possibilities of the present (Schaap, 2003, 6). It extends respect for the other as the co-builder of a common world and is communicated in a way that pervades the general, societal understanding so as to be recognized by virtually everyone. In this way, Schaap's political forgiveness is not found within the Kantian or Arendtian depiction of the political; it is not founded on the development of reason but on the recognition of coexistence within a particular space and time. Importantly, it does not ignore the judgement of the wrongness of an act; instead, it disregards the judgement that an action obligates one to consider the other as an enemy in the present (Schaap, 2003, 7). Political acts of forgiveness thus allows for political reconciliation as they create space for mutual acceptance, responsibility, and the opportunity to move beyond what might otherwise be considered irreconcilable differences.

Part and parcel of broader reconciliation processes, whether they are on a personal or political scale, is the pursuit of justice in post-conflict settings. Proponents of restorative justice hold a very different view of criminal justice from the prevailing understanding of crime and punishment. As Minow (1998, 92) defines it, "Restorative justice emphasizes the humanity of both offenders and victims. It seeks repair of social connections and peace rather than retribution against the offenders. Building connections and enhancing communication between perpetrators and those they victimized, and forging ties across the community, takes precedence over punishment or law enforcement." While restorative justice opens up the possibility of achieving both personal and political reconciliation, as Minow suggests here, we continue to distinguish between the two throughout this paper and concentrate on the achievement of the latter through restorative practices within a post-genocide, Rwandan context. On the other side of the same coin, we ask how the more common or traditional retributive justice initiatives have facilitated or impaired Rwanda's journey toward political reconciliation.

\section{Retributive and Restorative Justice Practices}

At present, both traditional Rwandan restorative practices and contemporary Western-inspired retributive practices are being employed in an effort to provide justice to the people of Rwanda. But this approach can leave the impression that justice is simply being cobbled together or is susceptible to the way the 
political winds blow. Further, it might also seem that the government's stated commitment to reconciliation is largely rhetorical, as victims are left feeling terribly insecure while offenders are not held accountable for horrific crimes. Practitioners and theorists of restorative justice argue that reconciliation will not be achieved by retributive practices, as these seek to establish guilt and punish offenders rather than to repair the breach that has been created by the offense. As Zehr (2005, 79-82) points out,

The justice process ... requires dependence upon proxy professionals who represent offender and the state. This, in turn, removes the process of justice from the individuals and the communities which are affected. Victim and offender become bystanders, nonparticipants in their own cases .... The justice process does not seek reconciliation between victim and offender because the relationship between victim and offender is not seen as an important problem.

With this in mind, it is also unsurprising that there are often rules prohibiting any contact between victims and offenders in Western criminal justice systems. These rules are intended to protect victims from further harm, of course, but they foreclose any hope for personal reconciliation at the same time. Because the retributive system either discourages or prevents victims and offenders from interacting with one another, stereotypes are maintained on both sides, offenders need not take responsibility for the harm they have caused, and victims cannot gain access to information that only offenders can provide.

Victims and their loved ones have a deep desire for answers and, more often than not, criminal trials do not address it: "They need real information, not speculation or the legally constrained information that comes from a trial or plea agreement" (Zehr, 2002, 14). Frequently, victims want a reason that explains why they were targeted and, while there is often no such reason, they can benefit a great deal from learning that their actions had nothing to do with their victimization. In the case of grave violations of human rights, as occurred in Rwanda, many victims want to know about the fate of loved ones or the whereabouts of their remains. It seems clear, with regard to offenders, that accountability is both important to and desired by victims and the community. Holding offenders accountable for their actions, however, might also work to discourage future offenses, as Zehr $(2005,40-41)$ argues that they are less likely to "believe that what they did was not too serious, that the victim 'deserved' it, that everyone is doing it, that insurance will take care of any losses." But a retributive system allows an offender to avoid taking responsibility for his actions: "His lawyer will talk to him about guilt in technical terms, and the process may encourage him to deny his guilt .... Meanwhile, he may see a psychological evaluator or therapist who will help him to understand his behavior in psychological terms, possibly muting his sense of personal responsibility" (Zehr, 2005, 69). Only when offenders take responsibility for the harm they have caused can victims begin the difficult process of reconciling with them, especially by asking for and receiving the information they need from offenders.

Thus, if personal reconciliation is a goal then interaction between victim and offender is a necessity. Indeed, the Victim Offender Reconciliation Programs (VORP) in North America focus primarily on bringing victims and offenders to- 
gether to engage in meaningful dialogue about the harm that occurred. These programs were pioneered by Mennonite communities in Ontario and Indiana, and involve "a face-to-face encounter between victim and offender in cases which have entered the criminal justice system process and the offender has admitted the offense" (Zehr, 2005, 160-161). In this way, VORP works in conjunction with the retributive system, but seeks a very different end. Rather than focusing on guilt and punishment, VORP emphasizes "three elements: facts, feelings, and agreements" (Zehr, 2005, 161). The key to the process is that both the victim and offender are able to tell their stories and reach an agreement together about how the wrong can be made right. As Zehr $(2005,162)$ points out, "VORP provides opportunity for expression of feelings, exchange of information, and recovery of losses while leaving victims with a sense of empowerment." Benefits also accrue to the offenders, especially in putting a face to the harm they have caused and accepting responsibility for their actions. Further, since "they are real participants rather than bystanders, they too can experience empowerment" (Zehr, 2005, 162). The trouble, of course, is that the VORP model is atypical; more often than not, the offender does not express remorse or even admit the offense. In our criminal justice system, police officers must advise suspected criminals that anything they say can be used against them in court and defense attorneys routinely advise their clients not to testify at trial. While this is often an effective strategy when it comes to the adversarial criminal trial-making the most of the presumption of innocence-it does little to help the offender take responsibility for his actions. Indeed, it promotes the impression that justice is something that is done to the offender, rather than a process in which he or she actively participates (Kohen 2009).

\section{Personal Reconciliation: The Rwandan Gacaca Courts}

Importantly, the VORP model is typically used to resolve relatively non-violent crimes like theft, vandalism, and burglary. Putting it into practice in Rwanda in the aftermath of genocide might seem to be setting the idea of reconciliation up for failure. As one co-victim of the Rwandan genocide told Gourevitch (1998, 240), "People come to Rwanda and talk of reconciliation .... It's offensive. Imagine talking to Jews of reconciliation in 1946. Maybe in a long time, but it's a private matter." It seems clear that choosing to engage in the difficult work of personal reconciliation, between individual victims and those who have harmed them, should be a private decision. Restorative processes demand a great deal from victims and, though they also offer much, victims ought not to be compelled to participate. For those who make the choice to do so, however, the traditional Rwandan justice system of gacaca offers a time-tested method for bringing victims and offenders together. Especially when compared to the retributive system that largely fails to hold offenders accountable, this restorative approach has much to offer.

The gacaca court system - often translated as "justice on the grass" - has a great deal in common with the VORP model. Historically, it was employed to deal with non-violent offenses, like slander or property crimes. It focuses on truth-telling, offender accountability, and restitution for victims. Disputes are resolved by a group of elders, who listen to the stories of both parties before giving 
their opinions on how to resolve the case. More often than not, Temple-Raston $(2005,133)$ notes, "the case involved cows or land or water and could be remedied by reparations or a heartfelt apology." The goal is reconciliation between victims and offenders, while also restoring the offender to the place he occupied in the community prior to the offense. Rusesabagina $(2006,9-10)$ argues that the central feature of the gacaca system is its conclusion:

The two aggrieved men were required to share a gourd of banana beer as a sign of renewed friendship .... Whether you were the victim or the aggressor you had to strip yourself of pride and recognize the basic humanity of the fellow with whom you were now sharing a banana beer .... Everyone who showed up to hear the case was invited to sip the banana beer too, as a symbol of the accused man's reconciliation with the entire people.

In this way, the individuals arrive at a solution to their dispute together with the people in their community, who act as witnesses to the resulting personal reconciliation and then reconcile with the ostracized offender themselves.

It is important to note, of course, that reparation and reconciliation are quite different concepts. Offenders might be instructed by village elders to provide some sort of restitution to the victims and to the communities they have harmed. But personal reconciliation, despite Rusesabagina's claims, requires a great deal more effort; while offenders must physically provide the restitution that has been ordered, it is often the victims who are required to do very difficult mental and spiritual work in order to begin the process of reconciling with offenders. Dwyer $(1999,95)$ argues that personal reconciliation will only be possible in cases "where people have particular desires about their future relationships, where actions manifest the sincerity of these desires, and where people are able to engage in face-to-face encounters that facilitate the negotiation of acceptable interpretations of events." While the gacaca process, like VORP, involves an encounter between victims and offenders, it is clear that personal reconciliation relies on a desire - by the former - for a future relationship with the latter. In order to achieve personal reconciliation, there must be a breach that is subsequently repaired. While the breaches in question in Rwanda are all related to the genocide in some way, it is also often true that the victim and offender do not have a preexisting relationship. In cases where the parties have only the crime in common, personal reconciliation seems a very lofty goal, not simply because there is no prior relationship to reestablish. For although Zehr $(2005,181-182)$ argues that the crime itself establishes a relationship, personal reconciliation necessitates that the victim has a desire for the continuation of a relationship that stems from an offense.

Unlike the traditional gacaca system, the present iteration seeks to establish offender accountability while also serving the government's goal of catalyzing the slow-moving genocide trials. In its ideal form, the victims face the offender as he or she stands before the panel of judges and pre-selected witnesses. Residents of the community are required to attend the Saturday hearings and a significant portion of the population participates by asking questions or giving impromptu witness statements. Thus far, however, the results have been decidedly mixed and have also yielded several unforeseen problems. Rather than trying all of the offenders who have been apprehended, the gacaca courts currently focus 
on those accused of all offenses other than the major planning and directing of the genocide. These criminal categories have been periodically altered since the 2003 inception of gacaca, which might seriously undermine the original nature of communal inclusiveness and openness that was supposed to characterize it. The mutability of crimes, especially since March 2007, means that many individuals accused of very serious crimes - such as multiple murders - can now be tried by gacaca in seeming contradiction to its original purpose. Furthermore, the accused have rarely, if ever, been able to contest allegations that led to the assignment of their alleged crime to one category or another until the gacaca trial itself. This is particularly problematic given that the category assignment is the sole basis for severity of punishment rather than providing an option for less serious charges (Human Rights Watch, 2008).

In addition to these periodic alterations and outstanding procedural issues, problems persist regarding the individuals who preside over gacaca trials. Overseeing the trial process are nine elected community officials who also determine the final outcome and sentence of the offender. These officials have very littleif any-legal training and hold their positions because they are respected in their communities. However, the issues before them and the judgments they pronounce are often complex legal matters, such as the determination of intent to exterminate (Sarkin, 2001, 161). In certain jurisdictions, there also exists a perception of unfairness due to the high number of Tutsi judges. It might be the case either that the community genuinely felt these individuals were best suited for this role or that there were a very limited number of potential Hutu judges due to high rates of incarceration; regardless, this perception is notably better than those jurisdictions where elected judges themselves were later implicated in the genocide (cf. Des Forges, 1999). Further, there are concerns that the courts are used to settle personal scores, especially because of the lack of existing legal safeguards (cf. Temple-Raston, 2005, 110-113; 137-140), and much is made of the emphasis that is placed on the virtues of confession. Indeed, some suggest that confessing to a crime one did not commit is the most expeditious way to get through the quagmire of the Rwandan justice system (Neuffer, 2001, 260-262). In one such case, Joseph N. explains the problem he faced after 6 years of imprisonment: "what do you do if you really didn't kill someone, and people in your community claim you did? Do you lie? Do you confess just so you can get out of prison?" (qtd. in Temple-Raston, 2005, 138). In a recent comparative and relatively comprehensive case study on transitional justice, Fletcher, Weinstein, and Rowen $(2009,210)$ note the importance of local remedies that adhere to a society's cultural traditions within the transitional justice process. While it may ostensibly seem that gacaca falls within this description, the authors take particular time to observe, "we must caution, however, that what is local must not be subverted by the political as in the case of Rwanda" (Fletcher et al., 2009, 210). Notably, Rwanda was not one of the seven transitional justice cases examined in this study. Taken together, these shortcomings undermine hopes of a gacaca process that emphasizes accountability while still promoting a sound form of personal reconciliation between génocidaires and their victims.

While these criticisms are troubling, it is important to also consider both the national and international alternatives to gacaca justice. Whereas the mandate of 
the gacaca system does not extend to prosecuting the architects of the genocide, the International Criminal Tribunal for Rwanda (ICTR) focuses solely on these offenders. The failure of the international community to properly attach the label of genocide to the hundred-day massacre while it was happening resulted in significant distrust of the United Nations by the Rwandan Patriotic Front (RPF). Thus, in the genocide's aftermath, the idea of a tribunal sanctioned by the international community was viewed with a great deal of skepticism and even outright distrust by the newly formed Rwandan government (Neuffer, 2001, 129). Indeed, when the official Security Council vote was taken on the issue, in November 1994, Rwanda - which ironically held a rotating seat - was the only country to cast a vote in opposition. Apart from its general misgivings about the international community, the RPF-led government also voiced several practical concerns with the proposed tribunal. In particular, the tribunal's judges would not be Rwandans, to avoid concerns over ethnic identity and partiality; decisions about prosecutions and procedures would be made by international officials; and life imprisonment, rather than death, was the toughest penalty that any offender could face (Cobban, 2007, 41). Finally, and perhaps most importantly for the question of reconciliation, Arusha, Tanzania was chosen as the site for the tribunal in an attempt by the UN to avoid any perceptions of "victors' justice" that might have arisen from a tribunal in Kigali, Rwanda. The consequence, however, was that the new government came to view the tribunal as an assault on both its legitimacy and sovereignty. Further, the ICTR is little more than a distant mirage of a judicial process for many Rwandans (Humphrey, 2003, 499-503). The lack of mass media cooperation between Tanzania and Rwanda has resulted in considerable ignorance about the trials amongst those who would be most interested. In fact, many Rwandans refer to the proceedings as "the Arusha trials," showing a clear lack of ownership or familiarity with the ICTR.

Of course, though persistent, these are far from the only problems arising from attempts at transitional justice in Rwanda. Domestic criminal trials began almost immediately after the Rwandan judicial system was restored in 1996; these, however, were marred by allegations of partiality and lacked independence of prominent court officials. As the trials proceeded slowly, the government decided to make the process of justice more visible to the populace through a number of public executions. Roughly 4 years after the genocide, 21 higher-level génocidaires were executed by firing squad to the sound of cheers from Tutsi-dominated crowds. The executions took place at four locations across the country and were met with condemnation from the UN and various international human rights organizations (Standley, 1998, 1). In addition to these executions, there are also allegations of reprisal killings of civilians by RPF soldiers at public meeting places. In Kinyarwanda, the native language, the term kwitaba inama means "to attend a meeting." In the aftermath of the genocide, when these killings took place, there was a dark joke that kwitaba inama could be used interchangeably with kwitaba imana, which means "to die" (cf. Des Forges, 1999). ${ }^{2}$ Paul Kagame and other for-

2 Allegations of massacres committed by the RPF are not limited to reprisal killings in the aftermath of the genocide. Des Forges (1999) writes of RPF soldiers implicated in the killing of hundreds of civilians in the Ruhengeri prefecture, with some of the killings linked to the political beliefs of the victims. 
mer RPF officials have understandably decided to distance themselves from any reprisal killings against Hutus since the genocide. Despite this decision, the Rwandan government has not been particularly vigorous in pursuing prosecution of RPF war crimes (Human Rights Watch, 2008). This is not meant to minimize the genocide or crimes by the interahamwe; the degree and extent of the atrocities committed by the interahamwe militia were by all measures worse than those of the RPF. Rather, RPF impunity is important because it symbolizes the general manner in which the Rwandan government has approached the question of reconciliation. It is also important to note that the RPF came to power with few limitations that would restrict the establishment of a constitution and postconflict policy that centered on healing, reconciliation, and respect for human rights. As Jeremy Sarkin $(2001,146)$ notes, after the genocide, "the new government has the widest discretion to decide how it should deal with the past including unfettered power to bring the perpetrators of human rights abuses to justice." Rather than using their role instrumentally to set a foundation for future reconciliation, the RPF instituted retributive policies that undermined the possibility of forgiveness and might even have perpetuated the cycle of violence between Hutu and Tutsi. In choosing to imprison more than a hundred thousand Hutu without charges or trials, pursue death sentences against some génocidaires, and also arbitrarily release thousands of other potentially guilty Hutu, the Tutsi-led government has done little practical work to emphasize personal reconciliation between individual victims and offenders.

\section{Political Reconciliation: Building Trust Between Hutu and Tutsi}

Of course, many victims - perhaps most - have no desire to build or reestablish a relationship with the offenders who harmed them. But this should not be considered a stumbling block for the achievement of political reconciliation between groups comprised of those victims and offenders. Speaking to this point is Marius Schoon, a South African whose wife and daughter were killed in 1984 by a letter-bomb intended for him: "On the whole I'm in favor of the Truth and Reconciliation Commission. I think it's going to bring about national reconciliation. In my case, it's not going to bring about personal reconciliation" (qtd. in Dwyer, 1999, 95). Though the latter seems impossible to Schoon, it is particularly noteworthy that he views a restorative process - the Truth and Reconciliation Commission - as a vehicle for the achievement of political reconciliation between black and white South Africans. For although personal reconciliation requires a private decision on the part of victims, we want to argue that political reconciliation, between the Hutu and Tutsi groups, cannot be accomplished as a private matter. Instead, publicity is a necessary element, as highlighted by the South African model with its emphasis on a public accounting of apartheid era crimes. As Tutu $(2000,51)$ notes, both victim and offender hearings were conducted before attentive audiences, in person, on the radio, and "in the full glare of television lights." This public airing of the country's dark past made it difficult-if not impossible-for white South Africans to cling to a narrative that failed to include the daily injustices and horrors experienced by their black countrymen. This sort of publicity, then, speaks to the sort of reconciliation envisioned by Dwyer (1999, 
89), whose "account of reconciliation ... is that of bringing apparently incompatible descriptions of events into narrative equilibrium." While this focus on the creation of a common historical narrative is undoubtedly important in Rwandaas it was in South Africa and as it is in the aftermath of any offense-we argue that both personal and political reconciliation require a good deal more. As Dwyer $(1999,95)$ herself notes of South Africa, "reconciliation at the macro-level requires the credibility that can be established only by implementation of social and economic programs that concretely address the substantive injustices of apartheid." While we address this suggestion from Dwyer in the concluding section of our paper, applying it to the Rwandan case, we also want to argue that political reconciliation cannot proceed in the absence of both a public apology from prominent offenders and the offering of forgiveness from prominent victims the aforementioned act of political forgiveness.

As Govier $(2002,144)$ argues, "In the aftermath of serious conflict, for reconciliation to be lasting, some kind of trust must be built, and for that to happen, attitudes must change-hence the relevance for forgiveness." This understanding of political reconciliation paints quite a different picture from the one described by Dwyer $(1999,89)$, as her "narrative equilibrium" might be achieved even in the absence of trust between antagonistic groups. She suggests that "Coherent incorporation of an unpleasant fact, or a new belief about an enemy, into the story of one's life might involve the issuance of an apology and an offer of forgiveness. But it need not" (Dwyer, 1999, 96). We agree that individual victims need not forgive offenders, repentant or not, in order for political reconciliation to succeed; personal reconciliation is not a requirement for political reconciliation, though the achievement of the former certainly would not impact the latter negatively. However, in the absence of public apology and forgiveness by antagonistic groups, political reconciliation means little more than non-violent co-existence. Though the achievement of non-violent co-existence is undoubtedly a marked improvement over the continuation of hostilities, the sort of reconciliation that we have in mind is a far more robust-and longer lasting - one. As Govier $(2002,144)$ argues,
people cannot come together in a lasting way and co-operate as they will need to in a jointly run society if they remain angry, vengeful, suspicious, and in- secure. The need for forgiveness lies in its relevance to two very practical as- pects of reconciliation: co-operation and sustainability. Institution-building, economic development, and political processes require that people and people work effectively together. To do so, they need to co-operate and trust each other in significant respects.

In order to achieve political reconciliation of this sort, well-known victims must be willing to publicly forgive and notable offenders must publicly apologize or accept the proffered forgiveness, thereby acknowledging the wrongs they have committed. These are individual actors, of course, but it is important to recognize that their actions are also undertaken on behalf of their respective groups. While it might be the case that many individual victims will not forgive those offenders who directly harmed them, the public forgiveness offered by a representative of the victimized group should not be considered illegitimate. On the other side of 
the same coin, remorse expressed by representatives of the offending group can move political reconciliation forward, even when many individual offenders do not yet accept their own culpability.

The South African case is a very helpful one, once again, in setting out the prospects for political reconciliation even in the absence of personal reconciliation. ${ }^{3}$ Though achieving the latter would be difficult, if not impossible, in the absence of individual apology and forgiveness, the latter might well be accomplished through the actions of leaders who recognize the importance of re-establishing trust and cooperation. Perhaps the best-and best known-example is that of Nelson Mandela, whose actions after his release from prison were clearly undertaken to make a political statement. ${ }^{4}$ While many black South Africans were not prepared to extend their hands in forgiveness to white South Africans, Mandela sought to do so on their behalf. Nor was Mandela's forgiveness offered in response to an apology from his oppressors, many of whom were unapologetic. This unilateral forgiveness, offered by a prominent victim of apartheid, was the beginning of a process that culminated in the new South African constitution, with its emphasis on national unity, and in the Truth and Reconciliation Commission, tasked with the promotion of political reconcilia-

3 By drawing a limited comparison between the political leadership in post-apartheid South Africa and in post-genocide Rwanda, the problem often arises of applying a generalized transitional justice framework to extremely particular post-conflict scenarios. This specific issue extends beyond the political reconciliation theory we offer, and often has implications on attempting to comparatively study other cases of transitional justice. Fletcher et al. $(2009,209)$ observe that transitional justice theorists, and more importantly practitioners, "may overlook the limitations and history of the context in which these interventions will unfold." In short, "there is no tabula rasa society upon which transitional justice is inscribed. Context matters and it matters considerably" (Fletcher et al., 2009 , 209). This point is especially critical to highlight because it undermines the mistaken notion that any common transitional justice mechanism is a good one. Transitional justice, and specifically the process of political reconciliation in Rwanda, must be carried out with due diligence paid to the historical underpinnings of the conflict and the contextual background against which the genocide was perpetrated. That said, characteristically, Rwanda and South Africa diverged drastically from one another as post-conflict states. At the time of the conflict, South Africa was industrialized in urban areas, and had a comparatively strong rule of law and an established Western legal tradition (Fletcher et al., 2009, 188). Furthermore, the conflict in South Africa was ended by an internally negotiated political compromise and the country has not experienced any substantive international intervention to implement transitional justice processes. The Rwandan case stands in stark contrast on all fronts, including the choice to eschew a truth commission in favor of individual trials. These differences, however, do not undermine our suggestions about political reconciliation for Rwanda's political leadership. While acknowledging the importance of actions by the political leadership in divided societies emerging from conflict, we also recognize that these actions do not constitute a silver bullet for reconciliation efforts. The issuance of a public apology and offering of public forgiveness by prominent officials and perpetrators does not guarantee that political reconciliation will be achieved; instead, it is a vital step in an evolutionary process. Mandela's actions did not guarantee a sustainable peace in South Africa, but did demonstrate a strong commitment to addressing past violations and building a more cohesive South Africa.

4 Govier $(2002,69)$ offers several examples: “On the first day of his release, he stopped his car to greet a white couple on the road. In an early speech, he thanked Black Sash, a white women's organization that had worked against apartheid, his first white employer, Lazar Sidelsky, and the white people who had helped him during his years in jail. In a fashionable restaurant the day after his release, Mandela went around the dining room to shake hands with white businessmen, assuring them of his friendly attitude and desire to see a non-racial South Africa in which all people, including whites, would have an important role to play." 
tion. "The forgiveness that Mandela extended to his former enemies, especially whites, was a powerful factor providing South Africans with a sense of hope that their country could move forward, away from the brutalities of the past" (Govier, 2002, 77; Kohen 2009).

While the magnanimity of Nelson Mandela set the stage for a peaceful transition to multiethnic democracy in South Africa and laid the groundwork for political reconciliation between blacks and whites, it is likely far too soon to declare the process a complete success. In the Rwandan case, however, the most difficult work has yet to begin, for several reasons. First, and perhaps most obviously, the architects of the genocide have not been effectively held accountable for the irreparable harm they caused. Although handfuls have been prosecuted at the international level, as discussed above, the adversarial, retributive nature of the ICTR discourages honesty from the accused in the dock. Perhaps no clearer example can be found than of the defense put forward by Georges Rutaganda, whose attorney argued that

It is not Hutus who are guilty of this so-called genocide. We are convinced there was no genocide. It was a situation of mass killings in a state of war where everyone was killing their enemies .... There are a million people dead, but who are they? They are 800,000 Hutus and 200,000 Tutsis. Everyone was killing but the real victims are the Hutus. So they've got this so-called genocide all wrong (qtd. in Sarkin, 2001, 150).

Though a great deal of lip service has been paid to reconciliation, then, it seems clear that no public apology is forthcoming from those on trial at the ICTR, those convicted and serving prison terms for their roles in the genocide, or those who still remain at large.

In addition to the Rutaganda case, the stories of Jean Paul Akayesu and Augustin Misago highlight the rationalizations made by prominent Hutu officials accused of genocide. As the mayor of the Taba commune in April 1994, Akayesu was the primary authority figure in the area at the outset of the genocide. In the early hours of April 19, after an interahamwe militia member was killed, Akayesu made a public speech in which he declared that he held in his hands information about a Tutsi plan to exterminate Hutu; to emphasize his point, he waved papers in the air (Benesch, 2004, 64). In the immediate aftermath of this speech, the Taba commune exploded in violence. Akayesu's case was one of the first to be brought before the ICTR and, as the trial got underway, it became apparent that the evidence of his guilt in inciting genocide was overwhelming. In his defense, Akayesu offered a variety of rationalizations, including outright denial of any involvement in acts of sexual violence that took place in Taba. In the final decision against Akayesu, the President of the ICTR nicely summarizes the defense that Akayesu presented:

In the opinion of the Chamber, the defence case in essence is that he did not commit, order to be committed, or in any way aid and facilitate the acts with which he is charged in the indictment. Akayesu concedes nonetheless, that massacres aimed mainly at Tutsi took place in Taba commune in 1994. The defence argues that Jean Paul Akayesu was helpless to prevent the commission of such acts because the balance of fouls in the commune was in favour of the In- 
terahamwe, who were under the strict authority of one Silas Nkubimana .... It submits that as soon as the massacres became widespread, the accused was stripped of all authority and lacked the means to stop the killings. The defence state or stated further that Jean Paul Akayesu could not be required to be a hero to lay down his life in a futile attempt to prevent the massacres (Prosecutor v. Akayesu, 1998, 7-8).

There are a few points in Akayesu's defense that are particularly worth highlighting: first, he was divested of previous authority during the genocide; second, the interahamwe exercised primary authority in Taba; and third, there should not be any positive requirement of action on his part, as any attempt to stop the massacres would have been in vain.

Interestingly, the identical points are made by Augustin Misago, the Bishop of Ginkongoro, in his informal defense of his actions during the genocide. In a country where more than half of the populace identifies as Roman Catholic, Misago held a position of considerable influence in his prefecture. On May 4, the Bishop visited a group of ninety Tutsi schoolchildren, to whom he promised protection; a few days after his visit, the police massacred all of the children. Misago is also suspected of denying refuge to fleeing Tutsi and commenting to a Vatican representative that the Pope should "find a place for Tutsi priests because the Rwandan people do not want them anymore" (Gourevitch, 1998, 137). The claim of helplessness, put forward by Akayesu, is also made by Misago, who explains to Gourevitch $(1998,138)$, "I don't have an army. What could I do by myself? Nothing. That's elementary logic." In addition to his inability to assist those in need, he claims ignorance with regard to the deaths of the schoolchildren: "The unfortunate thing was that among those policemen there were some accomplices of the interahamwe. I couldn't have known that. These decisions were made in the army" (Gourevitch, 1998, 138). Although Misago was eventually acquitted of participating in the genocide by a Rwandan court, it is clear that-despite his position of influence-he failed to assist those in need (Simpson, 2000, 1).

What is striking about all three men-Rutaganda, Akayesu, and Misagois the focus they place on their own victimization. Rutaganda's attorney claims that the genocide was actually committed against the Hutu rather than by them, Akayesu's defense rests largely on his assertion that he was forced to flee the genocidal interahamwe himself, and Misago argues that he was the victim of misinformation at the time and remains the victim of a political conspiracy against the Catholic Church. These high-ranking officials hold a starkly contrasting view of events that transpired during the genocide from the one held by Tutsi victims. This gap in perception makes the possibility of political reconciliation especially bleak at present. Without basic agreement about the facts of the genocide-for example, that large numbers of Hutu citizens murdered their Tutsi neighbors and not the other way around -it becomes virtually impossible to reestablish trust between the antagonistic groups. The adversarial nature of the ICTR and Rwandan court proceedings creates a zero-sum game for defendants, discouraging them from being truthful about their roles in the genocide and encouraging rationalizations that might result in winning the game against prosecutors. If these prom- 
inent members of the offending group cannot express any recognition that they and their group are at fault for the harm that occurred, any forgiveness offered by the victimized group "will have all the force of an extended but unshaken hand" (Govier, 2002, 145).

Of course, it is also the case that the policies intended, by the Tutsi-led government, to foster political reconciliation within Rwanda are clearly implemented at a time and in a fashion that is decidedly in the sole interest of the RPF leadership. At the beginning of 2003, nearly 9 years after the genocide, an unelected executive ruled Rwanda and the populace was governed without a definitive constitution. The August 2003 elections saw Paul Kagame - the military genius behind the RPF's victory over the Hutu-led government's forces in 1994-win the presidency with a stunning $98 \%$ of the vote. Although the percentage is an outrageous one, the election received far less attention for its outcome than it did for comments made by Kagame, who "warned that he would 'wound' 'divisionists' who threatened to undermine national unity and reprimanded foreign donors who give money to "people to teach divisions'" (Des Forges, 1999; cf. Temple-Raston, 2005, 217-220). The election merely confirmed Kagame's political control over the country, as he had ascended to the presidency in 2000, following the ouster of then-President Pasteur Bizimungu (Temple-Raston, 2005, 226; 113). However, it is also noteworthy that European Union observers witnessed instances of ballotstuffing and procedural miscounting on ballots (Harding, 2003, 1). Further, the EU noted that the method of voting - by fingerprint - could very easily allow for the identification of voting choices made by the electorate (Reyntjens, 2004, 186). Numerous human rights and intergovernmental organizations also expressed concern about voter intimidation and threats leading up to and on election day. Writing for the Norwegian Institute of Human Rights, Samset and Dalby (2003, 45) aptly observe that

While Rwanda set an example to follow when it comes to the technical conduct of the polls, the NORDEM team remains concerned about the forceful signs, conveyed from a host of sources, that the electorate was strongly influenced to vote for the ruling party. The influences they were subject to, both prior to the campaigns, throughout them and on the days of election, combined to form a heavy pressure. Given the weight on this pressure on the individual voter, it can be questioned if Rwandans at large actually felt that they had a choice.

In addition to a general respect for human rights, an element of fair governance is necessary to escape a cycle of repression in emerging from ethnic conflict. Free and fair elections still have yet to take place in Rwanda, which continues to plague the process of political reconciliation. In fact, a quick comparison of Freedom House Reports between the years 1993 and 2008 suggest that Rwanda has made no substantive progress in the areas of both political rights and civil liberties (Freedom House, 2008). ${ }^{5}$

5 In the 2008 Freedom House Report, Rwanda scored a 6 and a 5 for Political Rights and Civil Liberties, respectively; these scores range from 1 to 7 , with 7 being considered the "Least Free." Rwanda scored identically in 1993, just months prior to the genocide. 
Nor have intimidation tactics by the RPF been limited exclusively to the 2003 election. In March 2005, Charles Kabonero, a Rwandan newspaper editor, was convicted of the vaguely defined crime of "divisionism" (Human Rights Watch, 2006, 2). In a recent human rights workshop in Rwanda, a discussion began about the current state of individual rights and Placide M. (2007), a participant who worked as a journalist, spoke privately about two colleagues who had been fired days earlier after writing articles that criticized Paul Kagame. Problems with the media are no surprise, particularly as the government has promulgated several vague laws that outlaw "genocidal ideology" and "divisionism," and frequently interprets dissent as precisely these violations (Human Rights Watch, 2006, 1; 3). Paul Kagame routinely suggests he is unifying figure and that the RPF-led government provides stability to a country that desperately needs it; thus, when individuals are critical of Kagame or the government, they are often arrested for attempting to undermine the unity of Rwanda (Mgbako, 2005, 206-207). Although both unity and stability are very important characteristics of a society emerging from the chaos and violence experienced during the genocide and its aftermath, critical examination and dissenting opinions are also necessary features of a fractured society that is on the mend. In their absence, there is little accountability for policies that are said to be in the best interest of political reconciliation but which might actually be meant to keep Kagame and the RPF in power.

In addition to the notable lack of dissent or debate regarding Rwanda's leadership, there remains the intransigent problem of determining the proper role of the charged terms "Hutu" and "Tutsi" in Rwandan culture. The government has instituted Ingando solidarity camps that implement reeducation programs with the purpose of eliminating these ethnic identity terms (Mgbako, 2005, 218). The terms "Hutu" and "Tutsi" were used by the Belgians as political tools to ensure the profitability of their colony; while the distinction existed prior to the colonial period, the privileging of the Tutsis by the Belgians left a deep divide that became the basis for cycles of violence and oppression that eventually yielded the genocide. And, though these terms were largely applied arbitrarily, according to racial mythology, they are very much a part of the lived experience of ordinary Rwandans, especially since ethnically motivated violence became so commonplace following decolonization (Gourevitch, 1998, 4762). On the surface, then, the policies of the government that seek to erase ethnic identity to form one Rwandan identity appear to make excellent sense. That said, a great many problems exist with the underlying assumptions used to justify policies such as the ethnic reeducation in Ingando camps. Marc Sommers and Elizabeth McClintock $(2003,35)$ observe that "limiting talk about ethnicity does not eradicate its potency. It might just send it underground." Indeed, the terms "Hutu" and "Tutsi" are no longer used in public, but the walls of public restrooms are vandalized with ethnic slurs and threats made by members of both groups. Further, there is a considerable amount of discussion of ethnicity, in the privacy of individual homes, and it usually involves demeaning comments about one group or the other. One Rwandan woman, Godlives Karangwa (2007), astutely describes the current state of ethnic dialogue as "putting fire under a table." 
A quick look at the population demographics of Rwanda makes clear that it is in the interest of Kagame and other Tutsi leadership in Rwanda to repress dialogue of ethnicity and ultimately erase the idea of ethnic groups in Rwanda totally (Reyntjens, 2006, 1109). Assuming that Rwanda gradually does democratize, instituting free and fair elections, there exists the very real possibility that individuals would vote largely along ethnic lines given the historical salience of "ethnicity" in Rwanda. This fact, coupled with the relatively low percentage of Tutsis in the aggregate population does not bode well for the current majorityTutsi government. As noted above, laws now exist regarding "genocidal ideology" and "divisionism," but vague definitions leave them open to interpretation; while these two terms are ostensibly used to label acts that could lead to genocide, they are instead frequently used for political purposes. The political use of these terms to label dissidents, individuals who publically reference RPF war crimes, and even those who are defense witnesses in trials of prominent participants in the genocide is well documented (Human Rights Watch, 2008). While the espoused goals of eradicating "divisionism" and "genocidal ideology" are laudable, the methods undertaken by the Rwandan government to reach these goals are questionable at best.

\section{Deficiencies of Unity as Reconciliation}

Thus far, we have covered a laundry list of problematic policies being implemented on the ground in post-genocide Rwanda: the lack of free and fair elections, the lack of constructive dialogue on ethnicity, the political uses of "genocidal ideology" and "divisionism," the ICTR existing as the only transitional justice method to deal with prominent players in the genocide, ethnic reeducation in Ingando camps, and a general trend toward state centralization in Rwanda. Taken together, these policies adopted by the Rwandan executive and parliament amount to a sort of "reconciliation through unity" approach to dealing with the past. In the past 15 years, this emphasis on unity unquestionably benefitted the RPF and enabled it to maintain its hold on power (regardless of one's position on the fairness of the 2003 elections). However, this brand of "reconciliation" stands in contrast to the political reconciliation we advocate. Rather than offering forgiveness to prominent génocidaires, Kagame has urged the ICTR to transfer their cases to Rwanda so they might be tried by a judicial system that does not meet international standards. This is not to suggest absolving the planners of the genocide of their crimes, a move which would effectively undermine hopes of accountability and justice for genocide victims and co-victims. Instead, we suggest that high-level Tutsi officials must take progressive, public steps to ensure a sustainable reconciliation by working with, rather than opposing, the Hutu population. By failing to hold RPF soldiers accountable for war crimes in the wake of the genocide, the Rwandan government has conveniently allowed Hutus like Georges Rutagunda to remain comfortably entrenched in their belief that there will never be a just response to RPF reprisal killings. Furthermore, by effectively criminalizing the use of "ethnic" terminology, long-standing feelings of victimization will remain buried. In a hushed but heated discussion behind closed 
doors, journalist Placide M. (2007) asked, "In fifty years, who will we tell our children who killed who?" Placide's remark points to the fact the terms "Hutu" and "Tutsi" presently hold very real meaning to many Rwandans, regardless of the socially constructed origins of the terms. In fact, more than a million Rwandans have been systematically murdered based on these categories. To abruptly dispose of them, then, does little to deal with the immense amount of weight and real world consequence they carried into the genocide, and that they still hold to the present day.

Of course, in considering these observations, a reasonable, and frequently asked, question is whether a certain level of state centralization is necessary in Rwanda to "keep a lid" on Hutu-Tutsi tension. ${ }^{6}$ Certainly in the months and years immediately following the genocide this suggested method of conflict mitigation was absolutely vital for security measures. At this point in time, 15 years after the genocide, it seems clear that the level of state centralization that exists in Rwanda is actively working counter to hopes of achieving a sustainable peace. The politicization of gacaca, political involvement in the judiciary, ethnic reeducation camps, and restrictions on free speech and expression are destructive to hopes of true democratization, reconciliation, and thus to hopes of preventing future violent conflict.

\section{Conclusion}

The lack of honest, public discussion about ethnicity in Rwanda poses serious problems for the process of political reconciliation. If these ethnic terms are wholly suppressed, it seemingly becomes impossible for the victimized group to forgive the offending group. For if the government was to undertake the difficult work of identifying prominent victims who might offer forgiveness to the Hutus as a group - or if Kagame, himself a refugee of Hutu-led violence, were to act as Rwanda's Mandela - these statements would be in direct contradiction of policies of ethnic reeducation. Further, the loose interpretation of terms like "genocidal ideology" and "divisionism" discourage any sort of public dialogue on the role that ethnic identity can or should play in Rwandan society. This discourse could potentially be very useful in setting the stage for political reconciliation, as it could establish a common understanding between Hutus and Tutsis collectively. Taken together, these policies not only move Rwanda further from a comprehensive attempt at political reconciliation, but make it virtually impossible for Hutus and Tutsis to begin rebuilding the trust that was so violently broken by the genocide.

That said, the absence of accountability on the part of offenders poses a challenge every bit as serious. There is a powerful strain of denial on the part of so many Hutu that, coupled with their own sense of victimization, poses a terrible risk for the future of Rwanda. In the aftermath of the genocide, Gourevitch (1998,

6 Gourevitch $(1998,37)$, recently writing in the New Yorker, observes that Paul Kagame is "unapologetically authoritarian, and Rwanda's stability has come at the expense of internal opposition and dissent." 
262) visited and interviewed the Hutu leadership, refugees in Zaire, who explain that "Rwanda was terribly misunderstood in the world: yes, the country had suffered a genocide, but it was carried out by the RPF, and Hutus had been the victims." While not all Hutu murdered Tutsi-and while many have suffered as refugees, in Rwandan prisons, or due to the stigma of presumed guilt-the persistence of the myth of an RPF-led genocide is likely to have disastrous consequences. Indeed, one of the principal strategies employed by the architects of the genocide, in early 1994, was to claim that the invading RPF intended to take over Rwanda and either enslave or murder its rightful Hutu inhabitants for the benefit of the Tutsi. These claims rang true to many Hutu due to the memory of collective victimization suffered at the hands of Tutsi during the colonial period. The continued emphasis on Hutu victimization encourages offenders to view their participation in the genocide as legitimate action in the face of their own potential victimization while clearly discouraging an apology to those Tutsi whose families were murdered or who were themselves in grave danger. This feeling of victimization is furthered by the perception amongst Hutu that members of the RPF are not held accountable for crimes they committed, as neither the ICTR nor the gacaca courts have jurisdiction to try these crimes.

Members of each group, then, can legitimately claim that they have been victims of violence and repression at the hands of members of the other. But, as Govier $(2002,153)$ points out, "A group's acknowledgment of its own victimization poses dangers of a cult-like and ceremonial sharing of group pain. In the 'weness' cultivated under the ethnic tent, a sense of victimhood may be created all too easily, and may too readily displace efforts to understand the complexities of the past." What is needed, then, is an understanding of the past that is developed collectively, a new narrative that takes into account the complexity of everything that both groups have experienced. To attempt this work, Jeremy Sarkin (2001, 167) suggests "a properly constituted, totally independent, non-government appointed commission in Rwanda," without which "anger, resentment, hatred, and revenge might be the order of the day."

With an historical consensus on past human rights abuses as a solid foundation, the Rwandan government would then need to overhaul a number of its post-genocide policies to truly encourage political reconciliation between Hutu and Tutsi groups. The Kagame government would do well to move more directly in the direction of restorative approaches to justice, as the zero-sum nature of retributive judicial processes are typically not conducive to building trust and cooperation between former antagonists. Indeed, the public executions and questionable court proceedings of the recent past have contributed to the continuation of a cycle of misunderstanding and distrust that took root in the colonial period. As many of the genocide's planners have been tried, either by the ICTR or Rwandan courts, future hopes for political reconciliation rest primarily on extra-judicial initiatives that include forgiveness and public apology. The best chance of their success lies with leaders who might provide the necessary spark for political reconciliation or even serve as a model for personal reconciliation. While this solution undoubtedly requires a great deal of work to be undertaken by both victims and offenders, who currently seem loath to do so, it sets the stage for a last- 
ing reconciliation between Hutu and Tutsi. In its absence, the future peace and stability of Rwanda remains an open and debatable question.

\section{Acknowledgments}

The authors would like to thank fellow presenters, discussants, and audience members at the annual meetings of the Southern Political Science Association and the Midwest Political Science Association for their insightful comments on earlier versions of this paper. Research in Rwanda was made possible through grants awarded by the Office of International Programs and the College of Arts \& Letters at James Madison University.

\section{References}

Arendt, H. (1958). The human condition. Chicago: University of Chicago Press.

Arendt, H. (1982). Lectures on Kant's political philosophy. Chicago: University of Chicago Press.

Asiimwe, A. (2007). Rwanda releases 8,000 genocide prisoners. Reuters Foundation AlertNet (February 19). http:/ / www.alertnet.org/thenews/newsdesk/L19299276.htm

Benesch, S. (2004). Inciting genocide, pleading free speech. World Policy Journal 21(2, Summer).

Cobban, H. (2007). Amnesty after atrocity?. Boulder: Paradigm Publishing.

Cochran, C. (2002). Joseph and the politics of memory. 64 The Review of Politics 64(3, Summer).

Des Forges, A. (1999). Leave none to tell the story: genocide in Rwanda. New York: Human Rights Watch. http://www.hrw.org/reports/1999/rwanda/

Dwyer, S. (1999). Reconciliation for realists. Ethics and International Affairs 13(1, March).

Fletcher, L. E., Weinstein, H. M., \& Rowen, J. (2009). Context, timing, and the dynamics of transitional justice: A historical perspective. Human Rights Quarterly 31(1, February).

Freedom House. (2008). Country ratings and status, FIW 1973-2009. http://www. freedomhouse.org/template.cfm?page $=439$

Gourevitch, P. (1998). We wish to inform you that tomorrow we will be killed with our families: Stories from Rwanda. New York: Picador.

Gourevitch, P. (2009). The Life After. The New Yorker, May 4.

Govier, T. (2002). Forgiveness and revenge. London: Routledge.

Harding, A. (2003). Rwandan poll 'not entirely fair.' BBC News (August 27). http:/ / news. bbc.co.uk/2/hi/africa/3183051.stm

Human Rights Watch. (2006, January). Country summary: Rwanda. http://hrw.org/ wr2k6/pdf/rwanda.pdf

Human Rights Watch. (2008). Law and reality: Progress in Judicial Reform in Rwanda. http://www.hrw.org/en/reports/2008/07/24/law-and-reality

Humphrey, M. (2003). International intervention, justice, and national reconciliation: The role of the ICTY and ICTR in Bosnia and Rwanda. Journal of Human Rights 2(4, December).

Karangwa, G. (2007). Personal Interview with Author at Centre Christus in Kigali, Rwanda (January 3). 
Kohen, A. (2009). The personal and the political: Forgiveness and reconciliation in restorative justice. Critical Review of International Social and Political Philosophy, 12(3), 399-423.

Mgbako, C. (2005). Ingando solidarity camps: Reconciliation and political indoctrination in post-genocide Rwanda. Harvard Human Rights Journal 18(Spring).

Minow, M. (1998). Between vengeance and forgiveness: Facing history after genocide and mass violence. Boston: Beacon Press.

Neuffer, E. (2001). The key to my neighbor's house: Seeking justice in Bosnia and Rwanda. New York: Picador.

Placide, M. (2007). Personal Interview with Author at Centre Christus in Kigali, Rwanda (January 4).

Prosecutor v. Akayesu. (1998). ICTR-96-4-T (September 2). http://trim.unictr.org/ webdrawer/rec/2681/

Reyntjens, F. (2004). Rwanda, ten years on: From genocide to dictatorship. African Affairs 103(411, April).

Reyntjens, F. (2006). Post-1994 politics in Rwanda: Problematising 'liberation' and 'democratisation.' Third World Quarterly 27(6).

Rusesabagina, P. (2006). An ordinary man: An autobiography with Tom Zoellner. New York: Viking.

Samset, I., \& Dalby, O. (2003). Rwanda: Presidential and parliamentary elections 2003. Oslo: Norwegian Institute of Human Rights/NORDEM. http://www.humanrights.uio.no/ forskning/publ/nr/2003/12.pdf

Sarkin, J. (2001). The tension between justice and reconciliation in Rwanda: Politics, human rights, due process and the role of the gacaca courts in dealing with the genocide. Journal of African Law 45(2).

Schaap, A. (2003). Political grounds for forgiveness. Contemporary Political Theory 2(1).

Simpson, C. (2000). Rwandan bishop cleared of genocide. BBC News (June 5). http:// news.bbc.co.uk/2/hi/africa/791907.stm

Sommers, M., \& McClintock, E. (2003). On hidden ground: One coexistence strategy in Central Africa. In A. Chayes \& M. Minow (Eds.), Imagine coexistence: Restoring humanity after violent ethnic conflict. San Francisco: Jossey-Bass.

Soyinka, W. (1999). The burden of memory, the muse of forgiveness. New York: Oxford University Press. Standley, J. (1998). From butchery to executions in Rwanda. BBC News (April 27). http://news.bbc.co.uk/2/hi/programmes/from_our_own_correspondent $/ 84120$. stm

Temple-Raston, D. (2005). Justice on the grass: Three Rwandan journalists, their trial for war crimes, and a nation's quest for redemption. New York: Free Press.

Tutu, D. M. (2000). No future without forgiveness. New York: Image Books.

Zehr, H. (2002). The little book of restorative justice. Intercourse: Good Books.

Zehr, H. (2005). Changing lenses: A new focus for crime and justice (3rd ed.). Scottdale: Herald Press. 